$\underset{\text { Columbia Business School }}{\text { Center on Japanese Economy and Business }}$

CENTER ON JAPANESE ECONOMY AND BUSINESS

日本经汶经営研究所

Working Paper Series

July 2013, No. 325

\title{
The Market for Corporate Subsidiaries in Japan: An Empirical Study of Trades Among Listed Firms
}

\author{
Ulrike Schaede and Tatsuo Ushijima
}




\title{
The Market for Corporate Subsidiaries in Japan:
}

\section{An Empirical Study of Trades Among Listed Firms}

\author{
Tatsuo Ushijima* \\ Aoyama Gakuin University \\ Graduate School of International Management \\ E-mail: ushijima@gsim.aoyama.ac.jp \\ Ulrike Schaede \\ University of California, San Diego \\ School of International Relations and Pacific Studies \\ Email: uschaede@ucsd.edu \\ * Corresponding author \\ Shibuya 4-4-25 \\ Shibuya-ku, Tokyo \\ 150-8366 \\ Japan \\ Tel. +813-3409-8544 \\ Fax: +813-3409-4167
}

February 2013

\section{Acknowledgement:}

We gratefully acknowledge research assistance from Aska Kuwabara, Hayato Urabe, Anna Teramachi, and Sayaka Kawamoto. Earlier versions of this paper were presented at UCSD, Stanford University, the Japanese Economic Association, the Asian Financial Association, and the Research Institute of Economy, Trade, and Industry. We thank all participants for helpful suggestions and comments, in particular Takeo Hoshi, Yasuhiro Arikawa, Hideki Miyajima, Michael Furchtgott, Richard Smith, and an anonymous journal reviewer. All remaining errors are ours. This study was partially funded by KAKENHI (Grant-in-Aid for Scientific Research) Grant Number 21530404. 


\begin{abstract}
We investigate trades of wholly- or partially-owned subsidiaries between firms listed on the Tokyo Stock Exchange (TSE) for the years 1996 to 2010, to explore the economic impact in terms of strategic refocusing, stock market valuation and performance effects. By pairing both sides to each deal, we show differences in firm characteristics, returns, and subsequent performance of buying and selling firms. Unlike mergers between whole firms, most subsidiary deals straddled different industries. Most sellers were larger, more diversified and less profitable than buyers. Our event study reveals that abnormal returns were positive for buyers yet insignificantly different from zero for sellers. However, subsidiary sales in the core business earned negative returns, the more so the larger the deal. An analysis of ex-post operating results shows that the performance of sellers often declined after the trade, in particular for firms that divested a core-related subsidiary. We conclude that subsidiary trades in Japan in this period contributed importantly to strategic repositioning and a more efficient use of corporate assets.
\end{abstract}

JEL classification: G34; L23

Keywords: Subsidiary; acquisition; divestiture; strategic repositioning; Japan 


\section{Introduction}

Since 1998 Japan has witnessed a sharp rise in corporate restructuring and strategic repositioning by large companies, sometimes referred to as “choose and focus” (Schaede, 2008). This line of argument posits that highly diversified firms have begun to exit businesses, either out of financial necessity after a decade of slow economic growth or due to a perceived need to be more focused and nimble to succeed in a changing global competitive environment. This repositioning is also reflected in an increase in the number of domestic mergers and acquisitions (e.g. Nomura 2006). Legal reforms regarding corporate reorganization and stepwise deregulation since 1997 have opened up a variety of new M\&A strategies that were previously impossible, just as a change in Japan’s shareholder structure away from the previously dominant stable cross-shareholdings has added new incentives for corporate managers to target increased performance and profitability.

However, little evidence exists on the exact link between this strategic repositioning and M\&A activities. The literature on Japanese M\&A has looked mostly at combinations of whole firms, which often occur between relatively specialized firms that have little need for refocusing (Ushijima 2010). Kang et al. (2000) showed that, unlike the subsidiary trades studied in this paper, about $80 \%$ of whole-firm mergers occurred in the same 2-digit industry. They found significantly positive acquirer abnormal returns to mergers announced between 1977 and 1993. Inoue and Kato (2006), studying whole-firm mergers for the years 1990 through 2001, found positive and significant abnormal returns to the shareholders of target firms. In contrast, Mehrota et al. (2011) found that mergers did not create wealth for the shareholders of the target firm during the years 1982-2003. Shifting the angle to operating performance following whole-firm mergers, Odagiri and Hase (1989), Yeh and Hoshino (2002), and Kruse et al. (2007) obtained mixed results. Most 
of these studies use data for the 1980s and 1990s.

This paper adds to this body of work by focusing on the growing market for corporate assets in Japan. We look at firms that divest/acquire a subsidiary trade, and we extend the time frame through 2010, thus capturing the important recent changes in strategic repositioning. Because Japanese firms have long and extensively used subsidiaries as an organizational vehicle for diversification (e.g., Kikutani et al., 2007), selling off subsidiaries can be considered the starting point for corporate refocusing. ${ }^{1}$ We are interested in both, the stock market reaction to subsidiary trades, and their effects on corporate performance. Thus, in this paper we investigate trades of wholly- or partially-owned subsidiaries between firms listed on the Tokyo Stock Exchange (TSE) for the period beginning with the onset of legal reforms regarding M\&A, from 1996 through 2010.

Recent research for the U.S. has suggested that, in contrast to whole-firm takeovers, shareholders of firms that acquire a subsidiary obtain positive and significant wealth gains of about 2-3\% (e.g., Fuller et al. 2002; Moeller et al. 2004; Eckbo and Thorburn 2008); for Europe, these were estimated at $1.4 \%$ (Faccio et al. 2006). To our knowledge, ours is the first study of subsidiary trades between Japanese firms. Methodologically, the innovation of this paper is to pair both sides to each transaction, which allows for a comparative analysis of stock market gains and ex-post performance for both, the buyers and sellers.

Our analysis proceeds in three steps. First, we compare firm characteristics of both parties to each deal, and identify several unique aspects of subsidiary trades. In contrast to whole-firm mergers, we find a low incidence of within-industry deals, of less than $20 \%$ at the

1 While firms could also refocus by trading an internal division or a plant, high-quality data for such trades are difficult to obtain. For instance, although Recof's M\&A database includes data on "business transfers" (trades of non-subsidiary assets), unfortunately it often lacks details regarding the content of these transactions. We leave a study of trades in other operating units for future research. 
2-digit level. Moreover, the relative size of trading partners suggests that in contrast to whole-firm mergers, productive assets flowed from larger sellers to smaller buyers. Thus, subsidiary trades in this period were an important complement to whole-firm mergers in recombining assets across firms. Many cases were consistent with proactive refocusing (choose and focus), where sellers divested a non-core business subsidiary while buyers consolidated by purchasing subsidiaries in their core businesses. And even though we find that buyers were typically more profitable than sellers, the new and growing subsidiary trade phenomenon in Japan is not simply a bailout story: only $20 \%$ of sellers in this period were in financial distress, here defined by the interest coverage ratio.

In a second step, we estimate abnormal returns to the announcement of a subsidiary trade, for both buyers and sellers, based on a matched sample of 149 transactions. Consistent with research for other countries, we find that subsidiary trades were beneficial to the acquiring firm's shareholders: the mean (median) cumulative abnormal return (CAR) on and before the announcement date was positive and significant at $0.8(0.7) \%$. In comparison, the mean (median) two-day CAR for sellers, while insignificant, was negative at $-0.3(-0.4) \%$. This finding is in sharp contrast to Bates (2005) and Hite et al. (1987) who reported positive abnormal returns to sellers for the U.S. Cross-sectional regression analysis reveals that these abnormal returns to buyers and sellers both increased with transaction size, suggesting that efficiency gains were generated for both parties to a deal. Yet, a surprising finding is that the correlation of abnormal returns with transaction size turned negative for firms that divested a subsidiary associated with their core business. Moreover, this inverse correlation was not just caused by distressed firms selling off crown jewels.

Finally, to better understand the stock market’s reaction to subsidiary trades, we examine 
the ex-post operating performance (in terms of ROA and sales growth) for our sample. We find that sellers, especially of core-related subsidiaries, underperformed their industries both before

and after the deal, even though the ex-post difference in profitability for buyers and sellers tended to decline. The median cumulated, industry-adjusted, sales growth rate over four years after the trade was $-16 \%$ for firms divesting in the core, as compared to $-6 \%$ for non-core divestors, and $+2 \%$ for buyers. These patterns suggest that firms often divested a subsidiary when they anticipated non-transitory adversarial shocks, and the market saw this divestiture as a signal of hitherto unknown problems in the seller's business conditions. On average, this negative signaling effect was strong enough to offset the positive effect of expected efficiency gains. The stock market reacted even more negatively to core divestitures, which were apparently seen as a move to transform the main business, and thus increased uncertainty associated with a drastic strategy change. Overall, our results indicate a strong link between subsidiary trades in Japan and strategic repositioning.

The paper begins, in Section 2, with a brief review of the literature and recent changes in Japan’s M\&A environment. Section 3 introduces the data and describes the characteristics of trades and firms in our sample, to highlight potential motivations underlying a subsidiary trade. In Section 4 we perform an event study to estimate announcement abnormal returns, followed by regression analysis to identify the determinants of abnormal returns. Section 5 examines the ex-post operating performance of firms engaged in subsidiary trades. Section 6 concludes.

\section{Literature Review and Background on Japan}

\subsection{Literature}

Existing research on acquisitions of public firms and their subsidiaries reveals that the 
implications for shareholder wealth range widely. While mergers and takeovers among public firms have received most attention, there is now also a growing body of research on subsidiary trades for the U.S. and Europe. It has been shown that, on average, such trades increase shareholder wealth for the acquiring firms (Fuller et al., 2002; Moeller et al., 2004; Faccio et al., 2006). There is also evidence from the divestiture literature that asset sales normally increase the value of sellers in the U.S. and Europe (Eckbo and Thorburn, 2008). Taken together, these studies suggest that shareholders on both sides of the deal tend to benefit from a subsidiary trade. Given that share price effects of M\&A vary widely across countries depending on legal, institutional, and economic conditions (Alexandridis et al., 2010), it is of great interest to analyze wealth creation through subsidiary trades in other regions, such as Japan.

How might a subsidiary trade create value? A first reason is efficiency gains, both for the firms involved and the overall economy. Research on plant turnovers has shown that manufacturing plants are generally transferred from less to more productive firms, and that the productivity of transferred plants increases under the new ownership (Maksimovic and Phillips, 2001; Schoar, 2002). Such increases in the efficiency of asset use can also be a source of value creation when a subsidiary changes hands. A second reason is strategic improvement. Research shows that asset sales are often undertaken to reverse excessive diversification. John and Ofek (1995) find for the U.S. that corporate focus tends to increase after asset sales and lead to improved operating performance. The divestiture literature documents that announcement returns to asset sales are even more positive for focus-increasing sales, i.e., when the seller divests a non-core business (e.g. Berger and Ofek, 1999).

In terms of creating value for the individual firms, the size of the transaction should matter, too. Mulherin and Boone (2000) divide underlying motives to trades of corporate assets 
into "synergistic" and "non-synergistic". Synergistic transactions transfer assets to higher-value users, thereby generating value that is shared by both parties to the deal. Non-synergistic motives include empire building, managerial entrenchment and even hubris, and in such cases the relationship between size of the deal and value should be negative for buyers, even though they may still benefit sellers that dispose of unnecessary assets. Mulherin and Boone (2000) argue that insofar as the motivation for a trade is to increase efficiency, abnormal returns should increase with the size of the traded asset. Indeed, they find consistently abnormal returns to the shareholders of asset-selling firms that are positively and significantly correlated with the value of the divested entity, normalized by firm value. In a similar vein, Bates (2005) estimates the effect of transaction size on abnormal returns to the seller, yet finds that the effect is positive and significant only if sale proceeds are expected to be paid out to shareholders. Adding to this, Fuller et al. (2002) provide evidence that abnormal returns to firms acquiring a subsidiary also increase with transaction size.

One issue that remains understudied in the subsidiary trade literature is the division of gains. To our knowledge, so far no studies have compared abnormal returns for a matched sample of subsidiary sellers and buyers. The fact that abnormal returns to subsidiary buyers tend to be positive has led to the widely-held view that the division of spoils is more balanced for subsidiary trades than it is for whole-firm takeovers, where gains mostly accrue to target shareholders. Hanson and Song (2000) found highly comparable abnormal returns to buyers and sellers in a matched sample of broader asset sales. However, as demonstrated by Ofek (1993) and Denis and Schome (2005), among others, asset sales are often induced by poor operating performance and high leverage, which can limit the selling firm's power to negotiate a good price. Officer (2007) found that subsidiaries of U.S. firms are traded at a discount relative to public targets and this 
discount increases if the seller is in need of liquidity. Because subsidiary trades in Japan greatly increased during a period of poor economic conditions, a "fire sale" motivation could be a factor in determining the division of gains between trading firms, as we will explore below.

\subsection{Japan's M\&A Environment}

The years 1997/98 marked the onset of deep crisis and reform in Japan. In what has been labeled a “strategic inflection point” by Schaede (2008), Japan’s industrial architecture and business setting underwent a major transformation. Institutionally, this period marked the decline of the main bank (previously the main agent of corporate restructuring), a steady diminution in the relevance of business groups, a change in employment practices, a transformation of subcontractor relationships, and most importantly for the purposes of this paper, a revision of literally all laws pertaining to business, and in particular M\&A. These reforms afforded firms more opportunities for restructuring and strategic repositioning.

Strategic repositioning was necessitated by the failure of the previously dominant diversification strategy, as reflected in declining overall profitability since the 1990s. Fukui and Ushijima (2007) show that diversification and performance were negatively correlated and argue that this negative relation became a trigger for a wave of restructuring beginning in the late 1990s. One early means of restructuring by diversified firms were so-called partial mergers (jigyō tōgō), whereby two firms spin out their same-industry businesses to form a new, focused entity jointly

owned by the parents. In an event study, Ushijima (2010) found positive and significant returns to these transactions for the parent firms.

Another impetus toward change was the liberalization of cross-border financial flows in 1998, which increased the role of foreign shareholders in Japan. In the late 1980s, about 75\% of 
shares held by domestic financial institutions and corporations, and only $7 \%$ were in the hands of foreign investors (TSE 2011). By 2011, the unwinding of cross-shareholdings had resulted in a more pluralistic ownership structure: about $27 \%$ of shares were held by foreigners, and $18 \%$ by institutional investors. Unlike the previous stable shareholders that valued size and stability, these new investors often pursue returns on investment, thus creating a need for firms to increase performance.

Prior to 1997, a convoluted and restrictive Commercial Code had thwarted radical strategic change by limiting the market for corporate assets. During the postwar period until the 1990s, institutional norms on lifetime employment and arduous restrictions on layoffs facilitated opening new businesses yet made exit difficult. It has been shown that creating subsidiaries was often simply motivated by a desire to shift excess personnel to affiliated firms (e.g., Onji 2012). Importantly, until 2000 Japan’s accounting rules had centered on unconsolidated reporting, making subsidiaries an effective means to hide inefficiencies. In addition to these defensive motives, firms also used subsidiaries to expand across industries, especially when embarking on unrelated diversification (Kikutani et al., 2007). As a result, in the 1990s many Japanese firms found themselves with a large number of wholly- or partially owned subsidiaries, some in business that were no longer a core concern and many without a positive profit record.

The introduction of obligatory consolidated accounting, effective 2000, was announced in 1998. In combination with the changing shareholder structure, the new disclosure rules pressured firms to clean up problematic subsidiaries. They demanded more flexibility to reorganize and restructure. After a decade of low economic growth, the government, too, identified this as a need and launched a complete overhaul of the Commercial Code through annual revisions beginning in 1998 that eventually resulted in the new Corporation Law of 2006. 
In 1998, the previously costly merger process was greatly simplified, accompanied by a new antitrust stance and the preparation to allow holding companies in 2000. In 1999, companies were allowed to repurchase their own stock ("treasury stocks”), and in 2000 an equity-swap and equity-transfer system were introduced. In 2001, new rules guided easier spin-offs and red tape regarding business transfers (asset sales) was reduced. Bankruptcy laws were also revised at this time, to introduce new options of restructuring for companies in distress. In 2004 it became possible to use treasury stocks to acquire another company, and in 2007 triangle mergers were allowed, along with another reform of the antitrust regime that aimed to speed up the review process for mergers (e.g., Schaede 2008).

As a result of these changes, Japan’s domestic M\&A market has grown substantially. According to Thomson data, almost 20\% of all domestic M\&A during the decade of 1999-2008 were trades in subsidiaries, whereas only $11.5 \%$ of M\&A activity occurred between two listed firms. Of these subsidiary trades, those that occurred between listed parent firms are the focus of our paper.

\section{Data}

\subsection{Sample}

We explore the domestic trade of privately-held, non-financial subsidiaries between publicly traded, non-financial firms in Japan between January 1996 and December 2010. Because ours is the first study of these transactions, we are interested in a wide range of issues: the identity and characteristics of the buyer and seller in each deal; the nature of the business that was traded; the apparent motivation for the deal for each party; the stock market response to each deal at the time of the announcement; and the ex-post operating performance of buyers and sellers. 
Our analysis is novel in that we look at both sides of the trade simultaneously. In order to estimate abnormal returns precisely, we limit our analysis to deals where both the buyer and the seller are listed on the first section of the Tokyo Stock Exchange. ${ }^{2}$

We began by downloading all domestic acquisitions of private, non-financial subsidiaries between TSE 1st-section non-financial firms from the Recof M\&A database, the leading supplier of M\&A information in Japan. We limited our dataset to deals in which the acquiring firm obtains at least $50 \%$ of the target, to ensure that we focus on cases of true ownership transfer. This search resulted in an initial sample of 333 deals. In 121 cases, the Recof database did not contain the acquisition price, and we had to omit those instances.

The next step was to match these deals with stock return data, sourced from the Nikkei NEEDS Financial Quest Database. We eliminated six deals from the sample, due to insufficient return data for at least one party. To estimate the stock market reaction, we set the first day the deal was reported in the news as the announcement date. To do so, we matched each deal with the earliest date of a newspaper report in at least one of the four largest Japanese financial newspapers: The Nikkei (Nihon keizai shinbun), Nikkei Industrial (Nikkei sangyō shinbun), Nikkei Finance (Nikkei kinyū shinbun), and Nikkei Distribution (Nikkei ryūtsū shinbun). A total of 34 deals were not reported in these newspapers, and were cut from our sample. Another 23 deals, while reported in at least one paper, were confounded with other events, such as firm-wide employment downsizing, the release of new financial results, or an earnings forecast. We also omitted these events, so as to be able to precisely estimate stock price effects caused only by the announcement of the subsidiary trade. Overall, 149 deals survived these filters, and these

\footnotetext{
${ }^{2}$ The problem of infrequent trade poses a serious challenge to expanding the sample to firms listed on TSE's second section and other exchanges.
} 
constitute our dataset. ${ }^{3}$ To evaluate firm characteristics associated with each deal, we downloaded accounting data for each company from the Nikkei NEEDS Financial Quest database.

\subsection{Deal Characteristics}

Table 1 describes the sample. As shown in Panel A, subsidiary trades increased sharply at the beginning of this century, consistent with the overall trend of M\&A in Japan and in line with the consecutive legal changes beginning in 1998. Panel B shows that the traded subsidiaries operated in a variety of industries, similarly distributed over manufacturing and non-manufacturing. Panel C explores the industry affiliation of buyer and seller at the 2-digit level. ${ }^{4}$ In the vast majority (85\%) of deals, buyers and sellers operated in different industries. This is in sharp contrast to previous studies of mergers, which reported that around $70-80 \%$ of mergers and whole-firm takeovers in Japan have traditionally occurred within the same 2-digit industries (Kang et al., 2000; Kruse et al., 2007). Our data therefore suggest that subsidiary trades complement these deals by recombining assets across firms and industries.

As mentioned in Section 2, throughout the postwar period (1960s-1990s) Japanese firms aggressively pursued diversification. Beginning in the late 1990s, however, diversification was identified as a cause of inferior performance. To explore refocusing motivations, Panel D partitions deals according to whether the traded subsidiary operated in the same 2-digit industry as the buyer's core business, and whether the subsidiary was associated with a core or non-core business of the seller. In line with existing research on refocusing, we identify a firm's core

\footnotetext{
${ }^{3}$ Fuller et al. (2002) and Moeller et al. (2004) suggest a cutoff point of $\$ 1$ million. Here we do not screen the sample by transaction value; if we followed their lead, we would lose seven transactions.

4 These data are drawn from the Recof database, which codes industries very similarly to the 2-digit classification of JSIC (identical for manufacturing). For brevity, we refer to Recof categories as 2-digit industries.
} 
business as the 2-digit industry to which the firm as a whole is assigned. We find that the ratio of firms buying a subsidiary associated with the core business was 53\%. On the other hand, refocusing was apparently a main motivation of sellers, as $79 \%$ of sold subsidiaries were associated with non-core businesses. Our data therefore point to a new trend of refocusing through subsidiary trades.

The mean and median transaction values were $¥ 5.3$ billion and $¥ 1.4$ billion (roughly $\$ 55$ million and \$15 million), respectively, as reported in Panel E. When transaction value is scaled by the market value of buyers' equity 21 days before the announcement, the mean (median) size was 3.6 (1.2) \%. When normalized by the sellers’ market equity, the mean (median) size was 4.6 (0.7) \%. Panel F shows that in roughly half of the deals in our sample, the buyer obtained full control over the target subsidiary. Moreover, in $89 \%$ of deals, the buyer did not previously have an equity stake in the target subsidiary (Panel G). Even though acquisitions through equity were allowed beginning in 1999, the vast majority of deals were settled in cash; as we see in Panel H, equity was used in only three transactions.

\subsection{Firm Characteristics}

Our first inquiry is into the motivation underlying subsidiary trades in Japan. Table 2 reports the comparison of mean and median values for operational and financial characteristics of acquiring and selling firms for the fiscal year preceding the deal announcement (except for the market value of equity which is measured 21 days before the announcement). The right-hand column shows the percentage of cases where the buyer's value is larger than the seller's. The first four items speak to size: assets, sales, market equity and the number of consolidated subsidiaries. For each of these variables, both in terms of mean and median, sellers were larger than buyers, 
although the difference in market equity is small and insignificant. The mean (median) total assets of selling firms was $¥ 1,672$ (769) billion, compared to ¥802 (205) billion for acquiring firms. While sellers on average reported 123 consolidated subsidiaries, buyers had only 55.

The relatively larger size of firms selling off a subsidiary is in sharp contrast to previous findings (in Japan and elsewhere) regarding whole-firm mergers. For instance, in their study of mergers between listed Japanese firms prior to 1999, Kruse et al. (2007) found the mean (median) market value of buyers to be twice (three times) larger than that that of the targets. The fact that the direction of asset flows in subsidiary trades is opposite from whole-firm mergers in terms of firm size suggests that these transactions are complementary mechanisms to reallocate assets across firms.

Next, we compare the operational scope of buyers and sellers, by looking at the number of reported business segments as well as the diversification index (one minus the Herfindahl index based on segment-level sales). Both measures indicate that sellers were significantly more diversified than buyers, which is consistent with a motivation to sell corporate assets to refocus (John and Ofek, 1995; Schlingemann et al., 2002). As we saw in Table 1, the sellers in our sample divested mostly non-core businesses.

Acquiring and selling firms also differed in profitability. The mean and median ROA, defined as operating income over total assets, were significantly higher for buyers. This difference is consistent with the view that corporate asset trades may be motivated by potential efficiency gains from moving assets to better owners (Maksimovic and Phillips, 2001; Warusawitharana, 2008). As we will show in Section 5, this difference is mostly attributable to the underperformance of sellers within their industry, rather than a superior performance of buyers. To explore whether financial distress plays a role in these transactions, we defined a firm 
as distressed if its operating income was less than interest expenses in the year prior to the event (similar to Hoshi et al. 1990, and Hoshi et al. 2011). Of the total, 20.1\% of sellers and 9.4\% of buyers fell into this category. Using a similar definition, Mehrota et al. (2011) found that 51\% (35\%) of mergers between listed Japanese firms in 1982-2003 involve a distressed target (bidder). In comparison, then, financial distress appears to be a relatively unimportant driver of subsidiary trades in Japan in our period of investigation.

The performance difference is less evident when Tobin's Q is used. We define Q as market equity plus book liability over total assets. While the mean Q was higher for buyers and significant at the 0.1 level, the median Q was not significantly different for buyers and sellers. The last two variables compare capital structure. Consistent with earlier evidence on corporate downsizing (e.g., Ofek, 1993; Denis and Shome, 2005), leverage - measured here in total debt over assets - was significantly higher for sellers. Sellers were also less liquid than acquiring firms, in that they held less cash relative to total assets. Overall, these data allow us to deduce two main motivations for subsidiary sales: a desire to downsize or refocus, and financial pressure to restructure.

To examine whether the same characteristics appear in a multivariate context, we conducted logistic regression analysis to compare selling firms to buying firms (base case). Table 3 shows that the coefficients on all variables (except for cash holdings) are significant and their signs are consistent with the univariate tests: sellers tend to be larger, more diversified, less profitable, and more leveraged. We conclude that inter-firm subsidiary trades in Japan between 1996 and 2010 were motivated in ways commonly also found for restructuring and repositioning elsewhere. 


\section{Stock Market Reactions}

\subsection{Event Study}

Our next question is how the stock market responded to these reorganization efforts. To estimate the valuation effects of a subsidiary trade, we performed an event study of transaction announcements. We set the first date on which a trade was reported in a Nikkei newspaper as the announcement date (day 0), and estimated abnormal returns to the shareholders of acquiring and selling firms as the prediction errors from the market model:

$$
A R_{i t}=R_{i t}-\left(\alpha+\beta \cdot R_{m t}\right)
$$

where $R_{i t}$ is the daily return of security $i$ on day $t, \alpha$ and $\beta$ are the market model parameters estimated by OLS over day -170 to day -21 , and $R_{m t}$ is the market return on day $t$. Our measure of market return is the TOPIX.

Table 4 reports the cumulative abnormal returns over day -1 and day 0 . We find positive and significant returns to the shareholders of acquiring firms. As shown in Panel A, the mean CAR to buyers was $0.8 \%$, significantly different from zero with a p-value of 0.014 . The median CAR was also positive at $0.7 \%$ and significant $(p=0.004)$. This shareholder wealth increase for buyers is consistent with evidence for U.S. and European firms. However, for sellers our results differ from existing findings (e.g., Bates, 2005): in Japan a subsidiary sale on average failed to increase shareholder wealth, as the mean and median CARs were negative though not significantly different from zero. ${ }^{5}$

\footnotetext{
${ }^{5}$ As one might expect from the larger size of selling firms, the mean and median combined returns based on the market value of equity on day -21 are also not significantly different from zero.
} 
As discussed above, the characteristics of buyers and sellers suggest multiple reasons for a subsidiary trade, which can complicate share price reactions. In Panels B through E of Table 4, we explore differing motivations in more detail. As laid out in Section 2, shareholder wealth should increase if the trade produces synergistic efficiency gains, and the wealth effect should increase with transaction size (Mulherin and Boone, 2000; Ray and Warusawitharana, 2009). In Panel B of Table 4, we compare abnormal returns by size of transaction, by dividing our sample in two halves: for buyers, a transaction is defined as "large" if its value normalized by the buyer's market equity is larger than the median for our sample, and "small" otherwise. Likewise, we divide sellers based on the transaction size relative to the seller's market equity. For buyers, our evidence is consistent with anticipated efficiency gains. Mean and median CARs were positive and highly significant for large transactions, but insignificant for small transactions. In contrast, for sellers no such size effect is apparent, as the mean and median CARs were not significant for either small or large transactions. Apparently, the market saw no particular efficiency gains for sellers, even if the divestitures were large. .

Another cause of abnormal returns could be a bargaining power differential if the seller is strapped for liquidity or in distress; i.e., if the transaction is a fire sale. Officer (2007) found that subsidiaries of U.S. firms are often sold at a discount relative to public targets, and that this discount increases if the seller is in need of cash. Panel C takes a closer look at whether distress had an impact on abnormal returns in Japan. Even though our period includes the second half of Japan's “lost decade” of the 1990s, we find only weak evidence for fire sales. The mean (median) CAR to subsidiary sales by distressed firms was negative at $-1.3(-1.4) \%$ but not significantly different from zero. In addition, firms buying a subsidiary from a distressed seller did not gain greater abnormal returns than firms trading with non-distressed sellers. We derive that our results 
are not driven by fire sales, and that the negative average return to distressed sellers was not caused by a division of gains favoring buyers.

Panel D sheds light on the possible connection of CARs with shifts in corporate strategy, by separating traded subsidiaries into core and non-core businesses for each party. Buyers enjoyed positive valuation effects if they invested in an expansion of their core business, for which the mean and median CARs were both positive and significantly different from zero. In contrast, the stock market reaction to a non-core acquisition was more mixed. Walker (2000) and Megginson et al. (2004) have shown that whole-firm mergers and takeovers focusing on the core are value-enhancing; we support this finding here for subsidiary trades.

For sellers, too, it matters whether the trade occurred in core or non-core segments of their business. For the sale of a non-core subsidiary, the mean and median CARs were -0.1 and $-0.2 \%$, respectively, both insignificantly different from zero. For a core subsidiary sale, in contrast, the mean and median CARs were negative and significant at -1.4 and $-0.6 \%$, respectively. John and Ofek (1995) have found that asset sales that increase focus are value-enhancing. Our results are consistent with their finding in that non-core sales earned a more favorable stock market reaction. To our knowledge, however, negative and significant returns to core subsidiary sales are so far unreported in the literature. We will explore this aspect of our results in more detail below.

A final consideration is whether the buyer assumes full or partial ownership of the subsidiary. While a full acquisition could be considered as too expensive or risky, a partial ownership stake might augur long, drawn-out battles with other owners. Panel E segments deals into those of $100 \%$ ownership transfer, as compared to all others (>50\%). ${ }^{6}$ The results support

\footnotetext{
${ }^{6}$ This information is missing for five transactions, which are excluded from the analysis.
} 
the latter fears of indecision: For buyers the mean and median CARs were significantly positive only for full takeovers. For sellers, in contrast, the extent of ownership associated with the deals makes no difference in terms of abnormal returns.

\subsection{Regressions}

In the next step, we estimate the determinants of announcement returns through regression analysis to isolate the effects of individual factors. Our regressions have two dependent variables: (1) CAR over day -1 and day 0 to the shareholders of the buyer; and (2) the same two-day CAR to the shareholders of the seller. As these returns are obtained for a matched sample of buying and selling firms, we employ the seemingly unrelated regression (SUR) framework to estimate determinants. That is, we take into account the correlation of error terms of buyer and seller returns within a given deal, which will be non-zero if unobserved transaction-specific factors affect the returns. The independent variables of our models are (1) firm characteristics: firm size (logged market equity), diversification, profitability (ROA), and leverage (debt-to-asset ratio); as well as (2) deal characteristics: the transaction value normalized by the market equity of each party, a "core” dummy that flags whether the deal falls into either party’s core business, and a distressed seller dummy. We also include the interaction between transaction size and “core”.

Table 5 reports estimation results. Model (1) estimates the simplest specification where transaction size is the only independent variable. This parsimonious specification examines whether the stock market anticipated that subsidiary trades generate efficiency gains in Japan. Recall that synergistic motives of asset trades imply that abnormal returns increase with the size of the transaction, especially for buyers. We find that the correlation between transaction size and 
buyer as well as seller CARs is both positive and highly significant. This suggests quite strongly that subsidiary trades on average generated an expectation of efficiency gains for both sides, consistent with our finding that subsidiaries were normally transferred from a less profitable to a more profitable firm. However, the intercept term in Model (1) is negative and significant for sellers. This suggests that for sellers, a subsidiary trade conveyed negative new information in addition to the positive anticipation of efficiency gains. This finding reconciles the positive effect of transaction size with our finding (in Table 4) that the average abnormal return to sellers was not significantly different from zero.

Model (2) introduces firm-level variables. For buyers, none of these are significant. For sellers, in contrast, two variables significantly correlate with abnormal returns. First, the coefficient for diversification is positive, underscoring rewards to correcting excessive diversification (John and Ofek, 1995). The effect of profitability is also positive, possibly implying that a more profitable seller can divest a subsidiary on more favorable terms. We will shortly examine this scenario in more depth.

Model (3) adds the core dummy to shed additional light on the motivation of refocusing. Again, effects differ for buyers and sellers. The coefficient on the core business dummy is positive for buyer CARs yet negative for seller CARs. However, these effects are statistically insignificant.

To explore whether anticipated efficiency gains differ depending on whether a deal is related to the firm's core or not, Model (4) introduces the interaction effect of transaction size and the core dummy. For buyers, the effect is positive but insignificant. In sharp contrast, for sellers the interaction effect is significantly negative. Note also that the absolute value of the estimated coefficient on the interaction term is larger than the main effect of transaction size in the seller 
CAR regression. Thus, when a firm sells off a subsidiary in its core business, announcement returns decrease, the more the larger the deal. ${ }^{7}$ To check the robustness of this negative correlation to outliers, we re-estimated Model (4) by winsorizing transaction value at the top and bottom 5\%. While not reported here, results are qualitatively the same: the interaction effect of transaction size and the core dummy on the seller CAR is significantly negative and larger in absolute value than the main effect of transaction size, which is positive and significantly different from zero. ${ }^{8}$

The inverse correlation between transaction size and abnormal returns to the shareholders of firms selling off a subsidiary in the core business is striking and, to the best of our knowledge, previously unreported in the literature. One possible cause could be financial distress: If the divesting firm was in distress, selling off a core subsidiary may have signaled a need to raise liquidity fast by selling off a “crown jewel”, regardless of negative repercussions on long-term performance. Moreover, in this scenario valuable assets may have been sold off below fair value due to the seller's weak bargaining power.

To examine the role of financial distress, Model (5) includes the distress dummy, which takes one if the interest coverage ratio was below one in the year prior to the deal, and zero otherwise. We find that investors reacted negatively to subsidiary sales by distressed firms, and the coefficient is significant at the 0.05 level. The effect of distress was economically large: ceteris paribus, the mean CAR from a subsidiary sale was $2.5 \%$ points lower for distressed firms than for healthy firms. However, the interaction term of transaction size and the core dummy remains essentially unaffected, suggesting only a weak link, if any, between a core subsidiary sale

\footnotetext{
${ }^{7}$ An F-test, not reported here, rejects the hypothesis that the sum of interaction and main effects of transaction size is zero for sellers, with $\mathrm{p}<0.01$.

${ }^{8}$ We obtain qualitatively the same result for buyer CAR as well.
} 
and financial distress. To further explore the effect of distress, we also looked at the interaction effect on CARs of seller distress and transaction size. While not reported here, we found that the interaction was not significantly different from zero. Another interesting result in Model (5) is that firms that acquired a subsidiary from a distressed seller did not obtain larger abnormal returns than firms trading with financially healthy sellers. Taken together, these results confirm that fire sales are not driving our overall results.

To shed additional light on difference between core and non-core divestitures, we estimated logistic models to compare firms divesting a subsidiary in the core business with those divesting a non-ore business. How these sets of firms differ from each other is of interest because a firm's decision of which business to divest is not random. While not reported here, we found that none of our firm-level variables, including leverage, profitability, and financial distress, has the power to discriminate between core and non-core sellers. ${ }^{9}$ Thus, how firms self-select into core and non-core divestitures remains ambiguous, at least from information publicly available at the time of announcement.

\section{Operating Performance}

Taken together, our regressions pose seeming contradictions. One the one hand, we find that investors generally expected a subsidiary trade to be mutually beneficial for buyer and seller, even though the seller's shareholders did not obtain wealth gains around the announcement date. On the other hand, we also find that the stock market responded qualitatively negatively to subsidiary sales associated with the core businesses, for reasons that are not immediately obvious. To gain more insights into the information content of subsidiary trade announcements, in the final

\footnotetext{
${ }^{9}$ Regression results are available from the authors upon request.
} 
step we examined the ex-post performance of trading firms. As measures we used ROA and the annual growth rate of sales, which we adjusted for industry effects by subtracting the 2-digit industry median of TSE-listed firms for each year.

Table 6 tries to address the first of the two puzzles, by comparing the adjusted values, separately for buyers and sellers, from one year before trade announcement (Year -1) to three years after (Year 3), as well as the difference in performance between both groups. Recall from Table 2 that the raw value of pre-announcement ROA was significantly lower for sellers. Table 6 shows that this is mainly because sellers generally underperformed their industry: the mean and median industry-adjusted ROA in Year -1 was negative and significant for sellers, but not significantly different from zero for buyers. Moreover, the industry-adjusted ROA of sellers remained negative and significant through Year 2 after the sale.

The performance gap between buyers and sellers is even more evident for the growth in sales. While for buyers, both the mean and median industry-adjusted growth rates of sales were significantly positive prior to the deal announcement, for seller the median was significantly negative. The gap widened in and after Year 0 due to further growth (decline) of buyers (sellers), and continued through Year 2. While not reported here, we found qualitatively similar results when looking at the growth in assets and employment. At one level, this might be expected following the sale of a subsidiary, especially with large deals, but sellers continued to underperform their industries through Year 2.

Looking at the longer-term effects, for buyers the abnormal growth rate was relatively short-lived and dissipated by Year 2. Perhaps buyers in this period acquired assets to grab a fleeting growth opportunity. The industry-adjusted ROA of buyers remained essentially unaffected by the trade. At first sight, this may appear to be at odds with the sign of anticipated 
efficiency gains that we identified in the stock price reactions. Recall, however, that most subsidiary trades were small relative to the size of buyers, and thus their effect on firm-level profitability was probably limited. At least our data suggest that buying another firm's subsidiary enabled the buyer to increase revenues without suffering a decline in profitability. Though not reported here, we found no decline in return on sales either, meaning that the profit earned by buyers actually increased on average after these deals.

On the other side, the sellers' underperformance persisted into Year 2. This suggests that the sale was done in anticipation of a non-transitory adversarial shock. While appreciating efficiency gains from the asset transfer, investors may have been aware of this forward-looking behavior and discounted firms that announced a subsidiary sale. In other words, the sale was interpreted as a signal of new or hitherto unrevealed problems in the seller's overall business conditions. Gombola and Tsetsekos (1992) posit that a similar signaling effect exists in the announcements of plant closures by U.S. firms, as they found both, negative market reactions as well as deteriorating ex-post operating performance, for firms that close plants.

To address the second puzzle - negative stock market reactions to sales in the core - we partitioned the sample into divestitures in core vs. non-core businesses, and looked at the industry-adjusted ROA and sales growth rate for sellers only. Table 7 shows that for non-core sellers, while both ROA and sales growth were below industry norms prior to the sale, ROA returned to the industry median by Year 2 and sales growth by Year 3. This supports the notion that refocusing was instrumental for the turnaround efforts by Japanese firms between 1996 and 2010.

For core sellers, however, the story differs, as they displayed a strong and persistent downward trend, in particular in revenue growth. Even though mean and median 
industry-adjusted sales growth rates were not significantly different from zero in Year -1 for these firms, they became significantly negative thereafter, and continued so through Year 3.

Cumulated from Year 0 to Year 3, the median industry-adjusted sales growth rate of core sellers was $-15.6 \%$, compared to $-6.0 \%$ for non-core divestors. The profitability of core sellers also declined: In Year 3, their mean and median industry-adjusted ROA was negative and significant at -1.3 and $-1.2 \%$, respectively

One explanation for the inferior ex-post performance of core sellers could be that these firms sold valuable assets vital to their long-term performance. Firms might have sold such assets if they were at the edge of failure and under imminent pressure to increase liquidity. However, as we reported earlier, core and non-core divestors were highly comparable in such variables as profitability, financial distress, and leverage. We therefore have no evidence that core sellers were particularly strapped for cash prior to the sale. To confirm, we looked at several case studies in our sample, based on press reports and also company documents. We found no indication of a systematic pattern that core sellers sold off superiorly performing subsidiaries. Rather, our strong impression is that subsidiary sales augured but did not cause a prolonged inferior performance.

On the other hand, the case studies revealed a clear common theme: many core subsidiary sales were motivated by the need for a drastic renewal of corporate strategy. ${ }^{10}$ Given this finding, we conjecture that selling off a subsidiary associated with the core business signaled to investors that managers were about to launch a drastic change in strategy. While perhaps necessary and beneficial for corporate renewal, just in and by itself such a transition increases

\footnotetext{
${ }^{10}$ A good example is Yasukawa Electric's divestment of its original business of industrial motors. The company had diversified into other businesses over time, and throughout the 1990s, the stagnant domestic economy and the rise of new competition had put huge pressure on Yasukawa to reconsider its strategy. In 2000, the company sold a subsidiary specializing in small motors to Nidec, a successful domestic competitor focused on industrial motors. Beginning with this divestiture, Yasukawa shifted resources away from motors to newer and more profitable businesses, such as motion controls and industrial robotics.
} 
uncertainty about the firm’s future. Organizational scholars have found that changing fundamental aspects of a firm's strategy is a lengthy and risky process that may fail altogether, especially in a turbulent environment (e.g., Carroll and Hannan, 2000). Uncertainty naturally varies with the nature and size of the transition attempt, and therefore one possible explanation for the increase in negative abnormal returns with core divestitures, especially those that are larger, is an "uncertainty discount”. In contrast to the U.S. (e.g., Eckbo and Thorburn, 2008), Japan's stock market did not react outright positively to corporate asset sales, perhaps not only because such transactions signal a potential future decline in firm performance, but also because strategic repositioning is still a relatively new, untested, phenomenon in Japan.

\section{Conclusions}

This paper analyzed the structure, motivation and stock market reaction regarding subsidiary trades between listed firms in Japan, as well as the ex-post operating performance of firms involved in such trades. Using a carefully constructed dataset of 149 cases over a period of 16 years through 2010, a comparative analysis of opposite sides to each deal revealed several aspects in which subsidiary trades in Japan differ from what we know about whole-firm mergers in Japan, and for subsidiary trades in the U.S. Not only was the incidence of trades within one industry low (fewer than $20 \%$ of cases involved firms in the same 2-digit level industry), but in terms of relative size of trading partners, productive assets were moved from larger sellers to smaller buyers. In addition, we found many cases consistent with proactive refocusing ("choose and focus"), as $79 \%$ of sellers - which were generally more diversified than buyers - divested subsidiaries affiliated with non-core businesses.

Our event study reveals that, in line with existing research for the U.S. and Europe, 
subsidiary trades were beneficial to the acquiring firm's shareholders, as the mean (median) cumulative abnormal return (CAR) on and before the announcement date was significant and positive at $0.8(0.7) \%$. In contrast, CARs to sellers were not significantly different from zero on average, even though investors expected both buyers and sellers to enjoy efficiency gains from the trade. Most surprisingly, for firms divesting a subsidiary in the core, the abnormal return was significantly negative, the more so the larger the transaction relative to firm size. To our knowledge, this negative correlation of transaction value and seller abnormal return has so far been unreported in the literature. Based on the ex-post operating performance of trading firms, we conjecture that subsidiary sales in Japan elicited both an anticipation of efficiency gains and an unfavorable market reaction as they may have signaled new negative information regarding the future performance of the announcing firm.

In sum, our results suggest that subsidiary takeovers have contributed importantly to a more efficient employment of corporate assets in Japan. The data support the notion that the goal of strategic repositioning has been an important engine of domestic M\&A growth since the late 1990s. Our results suggest some avenues for future research. We are curious whether subsidiary trades will continue to contribute to a correction of operational inefficiencies in large Japanese firms, or whether our period of analysis marked a special era of revision of the previous, excessive diversification. Another interesting avenue to explore further is the relatively unfavorable market response to divestitures in Japan, which appears to be an anomaly compared with the experience in other countries. 


\section{References}

Alexandridis, G., Petmezas, D., Travlos, N.G., 2010. Gains from M\&As around the world: New evidence, Financial Management 39, 1671-1695.

Bates, T.W., 2005. Asset sales, investment opportunities, and the use of proceeds, Journal of Finance 60, 105-135

Berger, P.G., Ofek, E., 1999. Causes and effects of corporate refocusing programs, Review of Financial Studies 12, 311-345.

Carroll, G.R., Hannan, M.T., 2000. The Demography of Corporations and Industries. Princeton, New Jersey: Princeton University Press.

Denis, D.K., Shome, D.K., 2005. An empirical investigation of corporate asset downsizing, Journal of Corporate Finance 11, 427-448.

Eckbo, B.E., Thorburn, K.S., 2008. Corporate restructuring: Breakups and LBOs, in: B. Espen Eckbo (ed.) Handbook of Empirical Corporate Finance, Volume 2. Elsevier: Amsterdam, Holland.

Faccio, M., McConnell, J.J., Stolin, D., 2006. Returns to acquirers of listed and unlisted targets, Journal of Financial and Quantitative Analysis 41, 197-220.

Fukui, Y., Ushijima, T. 2007, Corporate diversification, performance, and Restructuring in the Largest Japanese Manufacturers. Journal of the Japanese and International Economies 21 (3), 303-323.

Fuller, K., Netter, J., Stegemoller, M, 2002. What do returns to acquiring firms tell us? Evidence from firms that make many acquisitions, Journal of Finance 57, 1763-1794.

Gombola, M.J., Tsetsekos, G. P., 1992. The information content of plant closing announcements: Evidence from Financial profiles and the stock market reaction, Financial Management 21, 31-40.

Maksimovic, V., Phillips, G., 2001. The market for corporate assets: Who engages in mergers and asset sales and are there efficiency gains? Journal of Finance 56, 2019- 2065.

Hoshi, T., Kashyap, A., Scharfstein, D., 1990. The role of banks in reducing the costs of financial distress in Japan, Journal of Financial Economics 27, 67-88. 
Hite, G.L., Owers, J.E., Rogers, R.C., 1987. The market for interfirm asset sales: Partial sell-offs and total liquidations, Journal of Financial Economics 18, 229-252.

Hoshi, T., Koibuchi, S., Schaede, U. 2011. Corporate Restructuring in Japan during the Lost Decade. In: K. Hamada, A. Kashyap,. D. Weinstein, eds., Japan’s Bubble, Deflation, and Long-term Stagnation. Cambridge: MIT Press, 343-373.

Inoue, K., Kato H. 2006. M\&A to Kakaku (M\&A and Stock Prices). Tokyo: Toyo Keizai Shinbun-sha.

John, K., Ofek, E., 1995. Asset sales and increase in focus, Journal of Financial Economics 37, 105-126.

Kang, J.-K., Shivdasani, A., Yamada, T., 2000. The effect of bank relations on investment decisions: An investigation of Japanese takeover bids, Journal of Finance 55, 2197-2218.

Kikutani, T., Itoh, H., Hayashida, O., 2007. Business portfolio restructuring of Japanese firms in the 1990s: Entry and exit analysis. In: M. Aoki, G. Jackson, H. Miyajima, eds., Corporate Governance in Japan: Institutional Change and Organizational Diversity. Oxford: Oxford University Press, 227-256.

Kruse, T.A., Park, H.Y., Park, K., Suzuki, K., 2007. Long-term performance following mergers of Japanese companies: The effect of diversification and affiliation. Pacific-Basin Finance Journal 15, 154-172.

Lang, L., Poulsen, A., Stulz, R., 1995. Asset sales, firm performance, and the agency costs of managerial discretion, Journal of Financial Economics 37, 3-37.

Maksimovic, V., Phillips, G., 2001. The market for corporate assets: who engages in mergers and asset sales and are there efficiency gains? Journal of Finance 56, 2019-2065.

Megginson, W.L., Morgan, A., Nail, L., 2004. The determinants of positive long-term performance in strategic mergers: Corporate focus and cash. Journal of Banking and Finance 28, 523-552.

Mehrotra, V., van Schaik, D., Spronk, J., \& Steenbeek, O. 2011. Creditor-Focused Corporate Governance: Evidence from Mergers and Acquisitions in Japan. Journal of Financial and Quantitative Analysis, 46(4), 1051-1072.

Moeller, S.B., Schlingemann, F.P., Stulz, R.M., 2004. Firm size and the gains from acquisitions, Journal of 
Financial Economics 73, 201-228.

Mulherin, J.H., Boone, A.L., 2000. Comparing acquisitions and divestitures, Journal of Corporate Finance 6, 117-139.

Nomura. 2006. Trends in Japanese Company Related M\&As in 2005. Tokyo: Nomura Securities Co., Ltd., Investment Banking Research Dept.

Odagiri, H., Hase, T., 1989. Are mergers and acquisitions going to be popular in Japan too?: An empirical study. International Journal of Industrial Organization 7, 49-72.

Ofek, E., 1993. Capital structure and firm response to poor performance, Journal of Financial Economics 34, 3-30.

Officer, M.S., 2007. The price of corporate liquidity: Acquisition discounts for unlisted targets, Journal of Financial Economics 83, 571-598.

Onji, Kazuki, David Vera, and Jenny Corbett. 2012. Capital injection, restructuring targets and personnel management: The case of Japanese regional banks. Journal of the Japanese and International Economies 26, 495-517.

Ray, S., Warusawitharana, M., 2009. An efficiency perspective on the gains from mergers and asset purchases, B.E. Journal of Economic Analysis \& Policy 9, Article 43.

Schaede, U, 2008. Choose and Focus: Japanese Business Strategies for the21st Century. Ithaca: Cornell University Press.

Schlingemann, F. P., Stulz, R.M., Walkling, R.A., 2002. Divestitures and the liquidity of the market for corporate assets, Journal of Financial Economics 64, 117-144.

Schoar, A., 2002. Effects of corporate diversification on productivity, Journal of Finance 57, 2379-2403.

TSE (Tokyo Stock Exchange)(ed.), 2011. 2010 Shareownership Survey (Heisei 22nendo kabushiki bunpu-jōkyō chōsa no chōsakekka ni tsuite), at www.tse.or.jp/english/market/data/shareownership/b7gje60000003t0u-att/e_bunpu2010.pdf

Ushijima, Tatsuo. 2010. "Understanding partial mergers in Japan." Journal of Banking \& Finance 
$34: 2941-2953$

Walker, M.M., 2000. Corporate takeovers, strategic objectives, and acquiring-firm shareholder wealth, Financial Management 29, 53-66.

Warusawitharana, M., 2008. Corporate asset purchases and sales: Theory and evidence, Journal of Financial Economics 87, 471-497.

Yeh, T.-M., Hoshino, Y., 2002. Productivity and operating performance of Japanese merging firms: Keiretsu-related and independent mergers, Japan and the World Economy 14, 347-366. 
Table 1: Descriptions of sample subsidiary transactions

\begin{tabular}{|c|c|c|c|c|}
\hline $\begin{array}{l}\text { Panel A } \\
\text { Distribution by year }\end{array}$ & $\begin{array}{l}1996-1 \\
1999-2 \\
2002-2 \\
2005-2 \\
2008-2 \\
\end{array}$ & & $\begin{array}{c}\text { \# obs } \\
4 \\
17 \\
48 \\
52 \\
28 \\
\end{array}$ & $\begin{array}{c}\% \\
3 \\
11 \\
32 \\
35 \\
19 \\
\end{array}$ \\
\hline $\begin{array}{l}\text { Panel B } \\
\text { Industry of traded subsidiary }\end{array}$ & $\begin{array}{l}\text { Manuf } \\
\text { Non-m }\end{array}$ & uring & $\begin{array}{l}70 \\
79\end{array}$ & $\begin{array}{l}47 \\
53\end{array}$ \\
\hline $\begin{array}{l}\text { Panel C } \\
\text { Industry of trading partners }\end{array}$ & $\begin{array}{l}\text { Same i } \\
\text { Differe }\end{array}$ & tries & $\begin{array}{c}23 \\
126 \\
\end{array}$ & $\begin{array}{l}15 \\
85 \\
\end{array}$ \\
\hline $\begin{array}{l}\text { Panel D } \\
\quad \text { Subsidiary's business }\end{array}$ & $\begin{array}{l}\text { Buyer } \\
\text { Seller }\end{array}$ & $\begin{array}{l}\text { Core } \\
\text { Non-core } \\
\text { Core } \\
\text { Non-core }\end{array}$ & $\begin{array}{c}79 \\
70 \\
31 \\
118\end{array}$ & $\begin{array}{l}53 \\
47 \\
21 \\
79\end{array}$ \\
\hline $\begin{array}{l}\text { Panel E } \\
\text { Transaction size }\end{array}$ & $\begin{array}{l}\text { Transa } \\
\text { TV/Ac } \\
\text { TV/Se } \\
\end{array}$ & $\begin{array}{l}\text { ue ( } ¥ \text { million) } \\
\text { quity }(\%) \\
y(\%)\end{array}$ & $\begin{array}{c}\text { Mean } \\
5,292 \\
3.6 \\
4.6 \\
\end{array}$ & $\begin{array}{c}\text { Median } \\
1,485 \\
1.2 \\
0.7 \\
\end{array}$ \\
\hline $\begin{array}{l}\text { Panel F } \\
\text { Extent of takeover }\end{array}$ & $\begin{array}{l}\text { Full } \\
\text { Less th } \\
\text { Unkno }\end{array}$ & & $\begin{array}{c}\# \text { obs } \\
78 \\
66 \\
5\end{array}$ & $\begin{array}{c}\% \\
52 \\
44 \\
3\end{array}$ \\
\hline $\begin{array}{l}\text { Panel G } \\
\text { Pre-takeover equity holding }\end{array}$ & $\begin{array}{l}\text { Yes } \\
\text { No } \\
\text { Unkno }\end{array}$ & & $\begin{array}{c}13 \\
133 \\
3\end{array}$ & $\begin{array}{c}9 \\
89 \\
2\end{array}$ \\
\hline $\begin{array}{l}\text { Panel H } \\
\text { Means of payment }\end{array}$ & $\begin{array}{l}\text { Cash } \\
\text { Equity }\end{array}$ & & $\begin{array}{c}146 \\
3 \\
\end{array}$ & $\begin{array}{c}98 \\
2 \\
\end{array}$ \\
\hline
\end{tabular}


Table 2: Characteristics of firms engaging in subsidiary takeovers/sales

\begin{tabular}{|c|c|c|c|c|c|c|c|}
\hline & \multicolumn{2}{|c|}{ Buyer } & \multicolumn{2}{|c|}{ Seller } & \multicolumn{2}{|c|}{$\begin{array}{l}\text { P-value of } \\
\text { difference }\end{array}$} & \multirow{2}{*}{$\frac{\text { Buyer }>\text { Seller }}{(\%)}$} \\
\hline & Mean & Median & Mean & Median & Mean & Median & \\
\hline Total assets (billion yen) & 802 & 215 & 1,672 & 769 & 0.000 & 0.000 & 28 \\
\hline Sales (billion yen) & 894 & 215 & 1,997 & 784 & 0.000 & 0.000 & 30 \\
\hline Market equity (billion yen) & 551 & 130 & 696 & 295 & 0.204 & 0.051 & 44 \\
\hline \# Consolidated subsidiaries & 55 & 22 & 123 & 64 & 0.000 & 0.000 & 24 \\
\hline \# Reporting segments & 3.2 & 3 & 4.3 & 4 & 0.000 & 0.000 & 21 \\
\hline Diversification index ( 1 - Herfindahl index $)$ & 0.35 & 0.40 & 0.50 & 0.57 & 0.000 & 0.000 & 33 \\
\hline ROA (operating income/ total assets, \%) & 6.3 & 5.3 & 3.7 & 3.3 & 0.000 & 0.000 & 64 \\
\hline $\begin{array}{l}\% \text { distressed firms (operating income }<\text { interest } \\
\text { expense) }\end{array}$ & \multicolumn{2}{|c|}{9.4} & \multicolumn{2}{|c|}{20.1} & \multicolumn{2}{|c|}{0.009} & \\
\hline $\begin{array}{l}\text { Tobin's Q (market equity plus book liability/total } \\
\text { assets) }\end{array}$ & 2.0 & 1.2 & 1.2 & 1.1 & 0.071 & 0.398 & 48 \\
\hline Debt/total assets $(\%)$ & 33.6 & 29.7 & 56.9 & 57.0 & 0.000 & 0.000 & 32 \\
\hline Cash/Total assets (\%) & 13.4 & 10.5 & 9.7 & 8.1 & 0.000 & 0.000 & 64 \\
\hline
\end{tabular}

Note: All values are for the fiscal year prior to takeover announcement, except for market equity (21 days before the announcement). 
Table 3: Logit regression to compare buying and selling firms

\begin{tabular}{lcc}
\hline & Coefficient & Standard Error \\
\hline Total asset & $0.183^{* *}$ & 0.088 \\
Diversification index & $1.328^{* * *}$ & 0.518 \\
ROA & $-6.358^{* *}$ & 2.862 \\
Debt / total assets & $0.097^{* *}$ & 0.038 \\
Cash/total assets & -1.449 & 1.671 \\
\hline Log Likelihood & -176.2 & \\
Pseudo R2 & 0.147 & \\
\# Observations & 298 & \\
\hline
\end{tabular}

Note: The dependent variable is a dummy variable, which takes the value of one for selling firms and zero for buying firms.

*** significant at the 0.01 level. ${ }^{* *}$ significant at the 0.05 level. 
Table 4: Cumulative abnormal returns on and one day before the announcement day

\begin{tabular}{|c|c|c|c|c|c|c|c|}
\hline & & $\mathrm{N}$ & Mean & (p-value) & Median & (p-value) & Positive \\
\hline Panel A: Tot & sample & & & & & & \\
\hline Buyers & & 149 & $0.8 \%$ & $(0.014)$ & $0.7 \%$ & $(0.004)$ & $58 \%$ \\
\hline Sellers & & 149 & $-0.3 \%$ & $(0.389)$ & $-0.4 \%$ & $(0.209)$ & $44 \%$ \\
\hline Combin & & 149 & $-0.2 \%$ & $(0.370)$ & $-0.2 \%$ & $(0.402)$ & $46 \%$ \\
\hline Panel B: Dec & nposition by transactio & & & & & & \\
\hline Buyers & Large & 74 & $1.7 \%$ & $(0.004)$ & $1.2 \%$ & $(0.000)$ & $65 \%$ \\
\hline & Small & 75 & $0.0 \%$ & $(0.883)$ & $0.1 \%$ & $(0.829)$ & $51 \%$ \\
\hline Sellers & Large & 74 & $-0.4 \%$ & $(0.632)$ & $0.0 \%$ & $(0.712)$ & $51 \%$ \\
\hline & Small & 75 & $-0.3 \%$ & $(0.273)$ & $-0.4 \%$ & $(0.069)$ & $36 \%$ \\
\hline Panel C: Dec & nposition by seller's fin & ial hea & & & & & \\
\hline Buyers & Distressed seller & 30 & $0.8 \%$ & $(0.333)$ & $0.8 \%$ & $(0.185)$ & $57 \%$ \\
\hline & Non-distressed seller & 119 & $0.8 \%$ & $(0.023)$ & $0.7 \%$ & $(0.011)$ & $58 \%$ \\
\hline Sellers & Distressed & 30 & $-1.3 \%$ & $(0.444)$ & $-1.4 \%$ & $(0.206)$ & $33 \%$ \\
\hline & Non-distressed & 119 & $-0.1 \%$ & $(0.703)$ & $-0.3 \%$ & $(0.622)$ & $46 \%$ \\
\hline Panel D: Dec & nposition by subsidiar & usines & & & & & \\
\hline Buyers & Core & 79 & $1.2 \%$ & $(0.025)$ & $1.2 \%$ & $(0.001)$ & $62 \%$ \\
\hline & Non-core & 70 & $0.4 \%$ & $(0.295)$ & $0.3 \%$ & $(0.533)$ & $53 \%$ \\
\hline Sellers & Core & 31 & $-1.4 \%$ & $(0.056)$ & $-0.6 \%$ & $(0.036)$ & $26 \%$ \\
\hline & Non-core & 118 & $-0.1 \%$ & $(0.862)$ & $-0.2 \%$ & $(0.716)$ & $48 \%$ \\
\hline Panel E: Dec & nposition by transferre & uity & & & & & \\
\hline Buyers & $100 \%$ & 78 & $1.0 \%$ & $(0.044)$ & $0.7 \%$ & $(0.021)$ & $58 \%$ \\
\hline & $<100 \%$ & 66 & $0.3 \%$ & $(0.375)$ & $0.4 \%$ & $(0.214)$ & $55 \%$ \\
\hline Sellers & $100 \%$ & 78 & $-0.6 \%$ & $(0.227)$ & $-0.4 \%$ & $(0.231)$ & $42 \%$ \\
\hline & $<100 \%$ & 66 & $-0.1 \%$ & $(0.868)$ & $-0.3 \%$ & $(0.733)$ & $47 \%$ \\
\hline
\end{tabular}

Note: P-values are based on t-test for means and z-test for medians. 
Table 5: SUR estimation results of the determinants of buyer and seller CARs

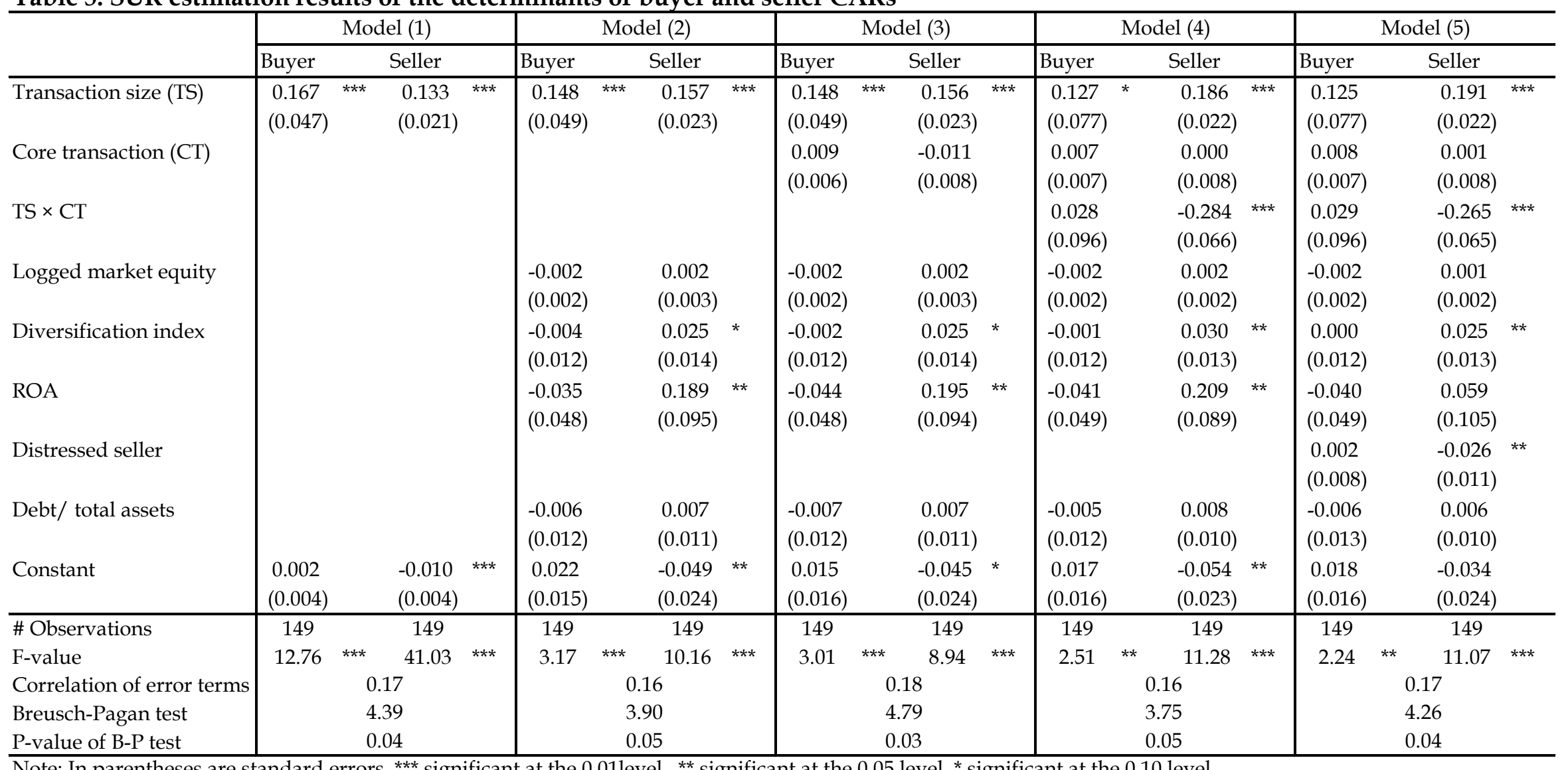

Note: In parentheses are standard errors. ${ }^{* * *}$ significant at the 0.01 level. ${ }^{* *}$ significant at the 0.05 level. ${ }^{*}$ significant at the 0.10 level. 
Table 6: Operating performance of buying and selling firms

\begin{tabular}{|c|c|c|c|c|c|c|}
\hline & & Year -1 & Year 0 & Year 1 & Year 2 & Year 3 \\
\hline \multicolumn{7}{|l|}{ ROA } \\
\hline \multirow[t]{2}{*}{ Buyer } & Mean & $0.7 \%$ & $0.3 \%$ & $0.1 \%$ & $-0.1 \%$ & $0.5 \%$ \\
\hline & Median & $-0.2 \%$ & $-0.5 \%$ & $-0.5 \%$ & $-0.5 \%$ & $-0.7 \%$ \\
\hline \multirow[t]{2}{*}{ Seller } & Mean & $-1.2 \% * * *$ & $-0.6 \% * *$ & $-0.3 \%$ & $-0.5 \%$ * & $-0.1 \%$ \\
\hline & Median & $-1.0 \% * * *$ & $-0.7 \% * * *$ & $-0.5 \%$ * & $-0.7 \% * * *$ & $-0.2 \%$ \\
\hline \multirow[t]{2}{*}{ Difference } & Mean & $1.9 \% * * *$ & $0.9 \%$ & $0.4 \%$ & $0.4 \%$ & $0.6 \%$ \\
\hline & Median & $0.8 \% * * *$ & $0.2 \%$ & $0.0 \%$ & $0.2 \%$ & $-0.5 \%$ \\
\hline \multicolumn{7}{|c|}{ Sales growth rate } \\
\hline \multirow[t]{2}{*}{ Buyer } & Mean & $3.7 \% * * *$ & $5.0 \% * * *$ & $6.4 \% * * *$ & $1.5 \%$ & $-0.6 \%$ \\
\hline & Median & $1.1 \%$ ** & $1.4 \% * * *$ & $2.0 \% * * *$ & $-0.5 \%$ & $-0.8 \%$ \\
\hline \multirow[t]{2}{*}{ Seller } & Mean & $-0.5 \%$ & $-2.1 \% * *$ & $-4.8 \% * * *$ & $-2.4 \% * * *$ & $-0.4 \%$ \\
\hline & Median & $-1.1 \% * * *$ & $-2.7 \% * * *$ & $-2.2 \% * * *$ & $-1.8 \% * * *$ & $-1.0 \%$ \\
\hline \multirow[t]{2}{*}{ Difference } & Mean & $4.2 \%$ ** & $7.1 \% * * *$ & $11.2 \%$ *** & $3.9 \% * *$ & $-0.3 \%$ \\
\hline & Median & $2.1 \% * * *$ & $4.1 \%$ *** & $4.2 \%$ *** & $1.3 \%$ ** & $0.2 \%$ \\
\hline \multicolumn{7}{|c|}{ \# Observations } \\
\hline \multicolumn{2}{|l|}{ Buyer } & 149 & 149 & 145 & 143 & 128 \\
\hline \multicolumn{2}{|l|}{ Seller } & 149 & 149 & 148 & 141 & 127 \\
\hline
\end{tabular}

Note: ROA and sales growth rate are both adjusted for the2-digit industry median for each year. The significance of mean (median) is based on t-test (z-test).

*** significant at the 0.01 level. ** significant at the 0.05 level. * significant at the 0.10 level. 
Table 7: Operating performance of firms divesting a subsidiary

\begin{tabular}{|c|c|c|c|c|c|c|}
\hline & & Year -1 & Year 0 & Year 1 & Year 2 & Year 3 \\
\hline \multicolumn{7}{|l|}{$\mathrm{ROA}$} \\
\hline \multirow[t]{2}{*}{ Non-core } & Mean & $-1.1 \% * * *$ & $-0.6 \% * *$ & $-0.3 \%$ & $-0.3 \%$ & $0.2 \%$ \\
\hline & Median & $-0.9 \% * * *$ & $-0.6 \% * * *$ & $-0.5 \% *$ & $-0.7 \%$ & $0.0 \%$ \\
\hline \multirow[t]{2}{*}{ Core } & Mean & $-1.6 \%$ * & $-0.6 \%$ & $-0.5 \%$ & $-1.2 \%$ & $-1.3 \%$ * \\
\hline & Median & $-1.5 \%$ * & $-0.9 \%$ & $-0.9 \%$ & $-1.1 \% * *$ & $-1.2 \%$ * \\
\hline \multirow[t]{2}{*}{ Difference } & Mean & $0.4 \%$ & $0.0 \%$ & $0.3 \%$ & $0.9 \%$ & $1.5 \%$ * \\
\hline & Median & $0.7 \%$ & $0.3 \%$ & $0.4 \%$ & $0.4 \%$ & $1.2 \%$ * \\
\hline \multicolumn{7}{|c|}{ Sales growth rate } \\
\hline \multirow[t]{2}{*}{ Non-core } & Mean & $-2.1 \% *$ & $-1.3 \%$ & $-4.1 \% * *$ & $-1.9 \% * *$ & $1.0 \%$ \\
\hline & Median & $-1.4 \% * * *$ & $-2.7 \% * *$ & $-1.9 \% *$ & $-1.0 \% * *$ & $-0.3 \%$ \\
\hline \multirow[t]{2}{*}{ Core } & Mean & $5.9 \%$ & $-5.1 \%$ * & $-7.4 \% * *$ & $-4.6 \%$ * & $-5.8 \% * *$ \\
\hline & Median & $0.0 \%$ & $-2.0 \%$ & $-3.7 \% * *$ & $-5.1 \% * * *$ & $-4.9 \% * *$ \\
\hline \multirow[t]{2}{*}{ Difference } & Mean & $-8.1 \% * *$ & $3.9 \%$ & $3.3 \%$ & $2.7 \%$ & $6.8 \% * * *$ \\
\hline & Median & $-1.4 \%$ & $-0.7 \%$ & $1.8 \%$ & $4.1 \%$ ** & $4.6 \% * *$ \\
\hline \multicolumn{7}{|c|}{ \# Observations } \\
\hline Non-core & & 118 & 118 & 117 & 113 & 102 \\
\hline Core & & 31 & 31 & 31 & 28 & 25 \\
\hline
\end{tabular}

Note: ROA and sales growth rate are both adjusted for the2-digit industry median for each year.

The significance of mean (median) is based on t-test (z-test).

*** significant at the 0.01 level. ${ }^{* *}$ significant at the 0.05 level. * significant at the 0.10 level. 